\title{
Management Considerations for Wheat Production in Florida'
}

\author{
D.L. Wright, A.R. Blount, R.D. Barnett, C.L. Mackowiak, N. Dufault, and J. Marois²
}

Higher wheat prices created the impetus for growing wheat in the southeastern United States. Since increasing amounts of corn have been diverted to ethanol production, there is a shortage of grain for America's livestock industry. This shortage results in higher wheat and soybean prices. Wheat and soybean have been grown together as a double crop throughout the Southeast for many years, which generally increases profitability compared with growing only one of the crops. Planting wheat followed by cotton, peanut or grain sorghum has also become a common practice. The best management practices for high yields of wheat in the Southeast Coastal Plain are well established. Listed below are production practices for small grains in Florida:

1. Field selection - Small grains grow best on fertile, welldrained soils. If corn or other grass crops do well, wheat should also produce good yields. Wheat may be planted after cotton, peanut or soybean harvest. However, restrictions may apply because of herbicides that were applied to the previous crop.

2. Crop rotation - Wheat should not be grown on fields that had wheat the previous year because of disease buildup (e.g. Septoria glume blotch) and Hessian fly problems. However, wheat may be rotated with oats or rye because neither is susceptible to Hessian fly infestation.

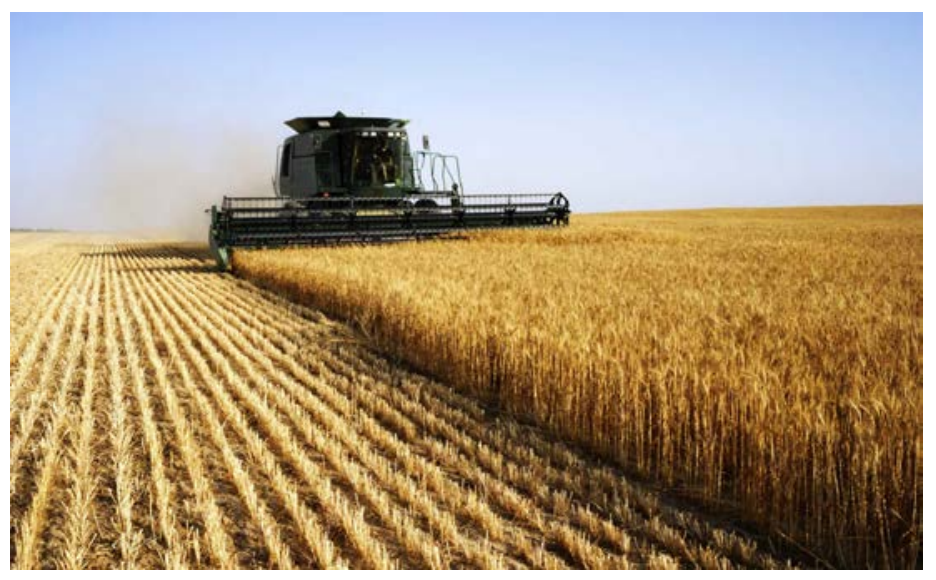

Figure 1. Harvest as soon as the wheat is adequately dried down to prevent lodging Credits: iStock

3. Deep tillage - Several years of UF/IFAS research has shown that either chisel plowing or other forms of deep tillage may result in yield increases from 5-15 bu/A (bushels per acre) compared with disking alone in preparing a seedbed. Deep tillage becomes especially important when drought occurs during the grain-fill period. Likewise, wet springs tend to leach nitrogen below the compaction layer, and the wheat's shallow roots are not able to pick up the deep nitrogen.

4. Variety selection - Choose recommended varieties that are high yielding, disease resistant, have strong stems, and have adapted to the area. Florida and

1. This document is SS-AGR-289, one of a series of the Agronomy Department, UF/IFAS Extension. Original publication date October 2007. Revised October 2013. Visit the EDIS website at http://edis.ifas.ufl.edu.

2. D.L. Wright, professor, Agronomy Department, North Florida Research and Education Center (NFREC)—Quincy; A.R. Blount, professor, Agronomy Department, NFREC—Marianna, FL; R.D. Barnett, emeritus professor, Agronomy Department, NFREC—Quincy; C. L. Mackowiak, associate professor, NFREC; J. Marois, professor, Agronomy Department, NFREC-Quincy; N. Dufault, assistant professor, Department of Plant Pathology. UF/IFAS Extension. Gainesvile, FL 32611. 
Georgia variety information can be found at www.swvt. uga.edu. Remember to always use high-quality seed.

5. Best time to plant - Plant during the first half of the recommended period (Nov. 7 to Dec. 1) with the normal period being between Nov. 7 and Dec. 15. Although Hessian flies may pose a problem with early plantings, wheat planted earlier can develop a better root system, which increases its ability to survive extreme winter temperatures. Full season varieties should be planted in early November and shorter season varieties in the first half of December. Normally, planting should not begin until one week before the average date of the first killing frost, which is Nov. 15 in northern Florida.

6. Use adequate seeding rates and depth - Use 30 to 35 seeds per square foot. Wheat varieties vary between 10,000 to 18,000 seeds per pound, so use seed counts, not bushels, when considering the amount of seeds needed. Most grain drills have rows 6 to 8 inches apart and would need to have about 18 to 21 seeds per foot of row when calibrating on those row spacings. Consider slightly decreasing the seeding rates for the earliest plantings and slightly increasing the rates at the end of the planting season. Higher seeding rates have not resulted in higher yields but have been associated with increased lodging. A seeding depth of $1-1 \frac{1 / 2}{2}$ inches is ideal under optimum conditions. If the fields will be grazed prior to production, use about $25 \%$ more seed.

7. Narrow rows - Rows spaced 4 to 5 inches apart have provided higher yields, but this may not be an important factor if wheat tillers well and is planted in early November. Only a few drills offer the option of 4 inch rows, and they may have problems planting through high-crop residue.

8. Weed control - If weeds are present, control measures should be taken early in the season when weeds are still small to eliminate competition. Wild radish and ryegrass should be treated soon after they are observed for effective control. Weed control information can be found at http://edis.ifas.ufl.edu/wg009.

9. Adequate fertility at planting - Use 20 to $30 \mathrm{lbs} / \mathrm{A}$ of $\mathrm{N}$ at planting, in addition to UF/IFAS recommended $\mathrm{P}_{2} \mathrm{O}_{5}, \mathrm{~K}_{2} \mathrm{O}$, and micronutrients as determined by a soil test. Many growers will apply all of the fertilizer $\mathrm{P}_{2} \mathrm{O}_{5}$ and $\mathrm{K}_{2} \mathrm{O}$ needed for both the wheat and soybean crop.
10. Timely nitrogen application - Florida research has shown that one timely nitrogen application near the third growth stage, or GS 3, (Feekes-Large), which usually occurs between the last week of January or the first 10 days of February, is adequate for optimum yields. However, on very sandy soils applications can be split between GS 3 (main shoot and seven tillers) and again about three to five weeks later; the Feekes scale can be found at http://gulf.ifas.ufl.edu/newsletters/2013/10/19/ wheat-production-considerations/. The growing season for wheat is short in Florida (November - May). Therefore, if rainfall amounts are low, wheat may not show responses to split $\mathrm{N}$ applications beyond one application in early February. Generally, top yields can be made with a total of 90-120 lbs/A of N applied between the planting and top-dress applications. The amount of $\mathrm{N}$ needed will depend on the previous crop, the amount of rainfall, and residual fertility. Further fertility recommendations can be found at http://edis. ifas.ufl.edu/ss163.

11. Sulfur applications - Yield responses have been noted to need sulfur on sandier soils. About 15 to $20 \mathrm{lbs} / \mathrm{A}$ of sulfur top-dressed with $\mathrm{N}$ should be adequate to meet plant needs. Sulfur needs may also be met by using sulfate of potash, magnesia or other sulfur-containing fertilizers.

12. Fungicides - Fungicides often increase economic yield, depending upon the severity of diseases. Inputs into producing wheat are becoming more expensive. Higher seeding rates and denser tillering may result in a better environment for disease development. Also, the springtime's wet weather, which is during the reproductive stages of growth, may lead to more disease. Information on wheat diseases and control can be found at http:// www.caes.uga.edu/commodities/fieldcrops/gagrains/ documents/Martinez_DiseaseMgmtWheat_20122013FINAL.pdf.

13. Irrigation - Although wheat is normally considered a non-irrigated crop and is grown in arid regions, irrigation may increase yields and test weight during very dry springs. In some years, one to two irrigations during grain-fill period can result in higher yields.

14. Harvest - Harvest as soon as the wheat is adequately dried down (about 12\% moisture) to prevent lodging and weathering losses (yield and lower test weight). To determine seed moisture, use a seed moisture meter. Harvest period depends upon the variety, but most 
adapted varieties will be ready for harvest by May 20 in Florida.

15. Economics - Higher yields are necessary to pay for the added cost when deep tillage, higher seeding rates, split or increased nitrogen applications, fungicides, and more occur. Budgets for wheat production can be found at http://www.ces.uga.edu/Agriculture/agecon/ budgets/printedbudgets.htm. 